Lonchinskaya, T.E. (2020). Renovation of the fan of the Empress Maria Feodorovna. Eurasia: Current Issues of Cultural Heritage. European Scientific e-Journal, 3(3), 63-72. Hlučín-Bobrovníky: “Anisiia Tomanek” OSVČ.

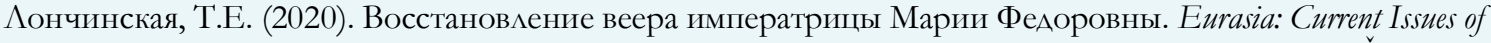
Cultural Heritage. European Scientific e-Journal, 3(3), 63-72. Hlučín-Bobrovníky: “Anisiia Tomanek” OSVČ.

$$
\text { DOI: } 10.47451 / \text { her2020-11-002 }
$$

The paper is published in Crossref, ICI Copernic, BASE, Zenodo, OpenAIRE, LORY, HSLU, J-Gate, Academic Resource Index ResearchBib, ISI International Scientific Indexing, eLibrary, Mendeley, and WebArchive databases.

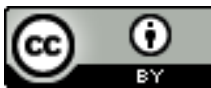

Tatiana E. Lonchinskaya, Candidate (PhD) of Pedagogical Sciences. St. Petersburg, Russia.

\title{
Renovation of the fan of the Empress Maria Feodorovna
}

Abstract: The works of lace-making art are our artistic heritage, material evidence of the creative talent and talent of Russian craftswomen. Speaking about the historical significance, aesthetic, artistic and expressive value of the lace fan of the Empress Maria Feodorovna, it is necessary to emphasize the reflection in them of technological traditions that determine the special attractiveness of hand-made artistic products, since they contain information about the lost technological techniques of lace weaving and the high skill of professional execution of ancient patterns. Study subject was the renovation of the Empress Maria Feodorovna's fan. The study purpose was to recreate a piece of lace-making art. The author discusses the lace fan of the Empress Maria Feodorovna. The author reveals the nature of lace ornament as a mean of artistic expression, which is due to the use of certain techniques of weaving. The significance of research of works of artistic lace weaving, renovation of the most valuable monuments of cultural heritage is proved.

Keywords: fan, Empress Maria Feodorovna, Mariinsky practical school of lace-makers, Russian lace, renovation.

Татьяна Евгеньевна Аончинская, кандиАат педагогических наук. Санкт-Петербург, Россия.

\section{Восстановмение веера императрицы Марии Федоровны}

\begin{abstract}
Аннотачия: Произведения кружевного искусства - это наше художественное наследие, материальное свидетельство творческого таланта и таланта русских мастериц. Говоря об исторической значимости, эстетической, художественной и выразительной ценности кружевного веера императрицы Марии Федоровны, необходимо подчеркнуть отражение в них технологических традиций, определяющих особую привлекательность художественных изделий ручной работы, поскольку в них содержится информация об утраченных технологических приёмах кружевоплетения и высоком мастерстве профессионального исполнения старинных узоров. Автор обсужАает кружевной веер императрицы Марии Федоровны. Предметом исследования была реставрация веера императрицы Марии Федоровны. Целью исследования было воссоздание произведения кружевоплетения. Автор раскрывает природу кружевного орнамента как средства художественной выразительности, которое обусловлено использованием определенных техник плетения. Аоказана значимость исследования произведений художественного кружевоплетения, восстановления наиболее ценных памятников культурного наследия.
\end{abstract}


Ключевъие слова: веер, императрица Мария Федоровна, Мариинская практическая школа кружевниц, русское кружево, восстановцение.

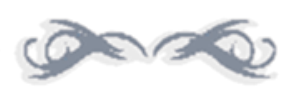

\section{Introduction}

The works of lace-making art are our artistic heritage, material evidence of the creative talent and talent of Russian craftswomen. Speaking about the historical significance, aesthetic, artistic and expressive value of the lace fan of the Empress Maria Feodorovna, it is necessary to emphasise the reflection in them of technological traditions that determine the special attractiveness of hand-made artistic products, since they contain information about the lost technological techniques of lace weaving and the high skill of professional execution of ancient patterns. Performing the artistic and creative process of renovation contributes to the reconstruction of highly artistic lace products with historical accuracy of highly artistic lace products.

Study subject was the renovation of the Empress Maria Feodorovna's fan.

The study purpose was to recreate a piece of lace-making art.

Based on the purpose of the study, the following tasks were defined:

- study the history of the fan's creation,

- get acquainted with the materials for the biography of Empress Maria Feodorovna,

- analyse the compositional solutions of the work,

- reveal the content of the renovation process of the lace-making art.

In 2005-2006, the students of the St Petersburg Higher School of Folk Arts (Institute) conducted research work of the article on the renovation of the fan of the Empress Maria Feodorovna under the guidance of the author. The lace fan of ecru color is kept in the collection of the State Hermitage Museum (Figure 1).

\section{History of the creation of the fan of Empress Maria Feodorovna}

The development of cultural values involves getting acquainted with the history of their origin and creation. Any work of art, any artistic event is determined primarily in time and space. We talk: "Lace fan. 1883. Russia”, "all-Russian handicraft exhibition, 1913, Petrograd”. For us, the social, cultural, artistic space-time continuum, in which "the key is the ethnic relatedness of the monument; the conditions of its occurrence are grasped as a moment of social, cultural and artistic evolution of the ethnic community" (Bernstein, 1979), is important.

The fan was presented as a gift to Empress Maria Feodorovna on the occasion of her birthday by members of the Board of Trustees of the Mariinsky Practical School of Lace-Makers. The school was opened in St. Petersburg on August 20, 1883. Training of instructors at this school contributed to the restoration of lost techniques of weaving, contributed to the development of the art of lace-making, and the revival of lace crafts in Russia. The famous Russian researcher Sofia Alexandrovna Davydova, who founded the Mariinsky Practical School of Lace-Makers, collected a unique collection of lace. In order to study the history and techniques of Russian lace production, she traveled to 11 provinces, visiting monasteries, museums, workshops, and storage facilities (Sorokina, 2001). The result of the study work was the book Russian Lace and Russian 
Lace-Makers. Historical, Technical and Statistical Research. The dedication reads: "To Her Majesty the Empress Maria Feodorovna, the faithful Sofia Davydova devotes her work with the deepest reverence." The book presents samples of lace, which are provided with a detailed description indicating the date, place of production, material and technique of weaving; historical, technical and statistical studies of lace crafts in the provinces of Russia. This book was a methodological guide for students of the Mariinsky Practical School of Lace-Makers. Sofia Alexandrovna Davydova wrote: "The lessons of school's students were so successful that they made it possible to make a lace fan in the form of an old fan for the Empress by November 14, 1883. E.E. Novoseltseva, N.P. Ilyin and me had the good fortune to present it to Her Imperial Majesty in Gatchina." (Bernstein, 1979) The first students of the school were two lace-makers from Vologda and two from Torzhok (Faleeva, 1983). It should note that since 1884 the school was given the name "Mariinsky", and since 1888 it had been under the royal patronage of the Empress Maria Feodorovna.

Thus, the fan of Empress Maria Feodorovna is the first creative work of students of the Practical School of Lace-Makers. The high artistic qualities of the fan reflect the history of the Russian Empire and indicate the high skill of lace execution.

\section{Materials for the biography of Empress Maria Feodorovna}

Empress Maria Feodorovna was born on November 26, 1847, in Copenhagen. Dagmar, born Princess of Denmark, was called Maria Sofia-Frederika-Dagmar before becoming Orthodox. As the daughter of king Christian IX of Denmark (1818-1906) and Queen Louise, she was engaged to the heir to the Russian throne, Grand Duke Nikolai Alexandrovich, but soon lost her fiancé, who died of tuberculosis in 1865. Fulfilling the last will of the deceased Nicholai Alexandrovich, the second son of Alexander II, Grand Duke Alexander Alexandrovich became engaged to a young Danish Princess in 1866. On October 28, 1866, the wedding of Alexander Alexandrovich and Princess Dagmar took place. Then she changed her name to LouiseFrederika-Dagmar and became Maria Feodorovna.

In 1881, her husband took the throne under the name of Alexander III. However, Maria Feodorovna herself had little interest in politics, although she made unsuccessful attempts to encourage the emperor to liberalise the system of government from time to time. Devoting herself primarily to philanthropic and charitable activities, she headed an extensive organisation that focused on medical education and charity. During the Russian-Turkish war (1877-1878), Maria Feodorovna became a nurse. In 1882, on the initiative of Maria Feodorovna, the Mariinsky women's schools for poorly educated and low-income city girls were established. Free matinees were given annually for students of the capital's educational institutions on November 14, Her Majesty's birthday. Maria Feodorovna was an honorary member of the Kazan University, head of the department of the Empress Maria's institutions, which included educational institutions, orphanages, orphanages for destitute and defenseless children, almshouses; as well as the head of the Russian Red Cross Society, chief of a number of army regiments including the cavalry guard and cuirassiers. The Empress patronized the Women's Patriotic Society, the Water Rescue Society, the Animal Welfare Society, and others. Maria Feodorovna died at the villa Vidora near Copenhagen on October 13, 1928, and was buried in Roskilde in the famous Cathedral, the tomb of the Danish kings (Grebelsky \& Mirvis, 1992). 
Maria Feodorovna was the only crowned person, who managed to survive the October revolution, and the only Russian Empress, whose ashes rested outside of Russia for many years. In 2001, the head of the Romanov Imperial house, Prince Nicholai, asked the authorities of Russia and Denmark to reburial the remains of the Russian Empress and mother of the last Russian Emperor Nicholai II, Maria Feodorovna, from the Cathedral of the Danish city of Roskilde to the Romanov family tomb in the Peter and Paul fortress in St. Petersburg. In October 2004, the President of Russia signed an order On an Interdepartmental Working Group to Organize the Ceremony of Transferring the Ashes of the Dowager Empress Maria Feodorovna, the Wife of Emperor Alexander III, from the Kingdom of Denmark and Burying in the Peter and Paul Cathedral in St. Petersburg. The burial ceremony of the ashes of the dowager Empress Maria Feodorovna was held on September 26, 2006 in the Peter and Paul fortress in St. Petersburg.

Thus, the study of the biographical materials of Empress Maria Feodorovna explains why the gift made to Empress Maria Feodorovna by students of the Mariinsky Practical School of LaceMakers is a lace fan, impressive by the nobility of the lines of the drawing of state power symbols. The date of 1883, engraved on the bone handle of the fan, coincides with the year of the coronation of Emperor Alexander III and the year of the foundation of the Mariinsky Practical School of Lace-Makers.

\section{The fan of the Empress Maria Feodorovna}

Fan is flat, hard screen, decorated with braided lace on bobbins. The fan size is not large: the fan screen is $49.5 * 27 \mathrm{~cm}$. The lace is set on a yellow satin lining. The handle is carved from ivory. The wooden case is decorated with relief carvings (Plotnikov \& Yakovlev, 1997). The fan impresses with the beauty of the openwork ornament and the precision of technical execution. The lace is made by a coupling technique of weaving with thin linen and silk threads.

There is a double-headed eagle with heraldic significance on the front side of the fan (Figure 2). In Russia, the imperial signs were the state eagle and crown. The appearance of the doubleheaded eagle in the coat of arms of Russia is usually associated with the marriage of John III and Sophia Palaiologos (1472). The oldest such monument in Russia is the eagle, depicted on the throne, which Sophia brought with her from Byzantium (Grebelsky \& Mirvis, 1992).

The dense lace pattern of a double-headed eagle stands out in contrast against the background of a four-sided tulle lattice. The image of an eagle is conventional, but the authenticity of a living figure is preserved. the wings have small feathers, and the heads are crowned with crowns. The lace pattern is distinct and expressive. In the center of the image on the eagle's chest there is the letter "M" surrounded by a chain made of linen, and round convex relief 'cones' made of 'plaits' are inserted into the chain links (Figure 4). The image is crowned with a central crown, i.e., the Monomakh's Cap. It should be noted that the Monomakh Cap is one of the oldest Russian medieval crowns, according to legend, sent by the Byzantine emperors Basil II and Constantine IX to the Grand Duke of Kiev Vladimir the Saint on the occasion of his baptism and marriage in 988. It is interesting that the lace drawing-chip of the Monomakh's Cap, as Sofia Alexandrovna wrote, was compiled and made according to the samples of old lace available at the school and presented in the album of Collection of Chips, Consisting under the August Patronage of Her Majesty the Empress Maria Feodorovna of the Mariinsky Practical School of Lace-Makers in St. Petersburg. 
In the side sectors of the front part of the fan, flowers with petals that are clearly arranged in helical spirals, are shown symmetrically relative to the central axis. The contours, described by vjushkoj with filigree "pigtail", stand out boldly charming the viewer. The composition is completed by a frill made of vilyushki with a filigree and a voluminous three-layer rosette located at the bottom. Flowers, ruffles' vilyushki augmented and enriched by vivaty loops that highlight the intricate lace.

On the reverse side of the fan, the composition of the lace image is different (Figure 3). In the center of the mirror composition, the letter " $\mathrm{M}$ " is depicted outlined with a cloth. The filling of the letter is made in the form of a flexible stem-platesat with leaves extending at regular intervals, tiny flowers and rhythmically alternating oval lattice medallions of the paired weaving technique. At the bottom, at the foot of the letter, there is a seven-petaled fairy flower.

Above the letter is an anthropomorphic character: a small figure with upraised hands. All parts of the complex composition are interconnected and reflect subordination, an appeal to the central anthropomorphic figure, which seems to send down a blessing to others. The original semantics are unknown. It is assumed that Andrew the First-Called is depicted there. The choice of the patron of the order is explained by the church legend about the first preaching of Christianity in the Russian lands by Andrew the Apostle; hence the epithet 'first-called'. The badge of the order was the oblique St. Andrew's Cross in blue enamel with the image of a crucified saint. At the ends of the cross were the letters SARP (Sanctus Andreas Russia Patronus, i.e., St. Andrew the Patron of Russia) (Spassky, 1963).

Above the anthropomorphic figure there is a crown as a symbol of royal power. Branches with flowers are symmetrically woven in the side parts. The flowers have seven elongated petals, are included in the pattern and rounded leaves with whorls of bizarre shapes, with a complex filling of plaits and mats. Below, a beautiful flowering shrub with bent shamrocks and patterned leaves rises from under a three-layer rosette. The large plane of the background grid gives the lace airiness and transparency. The braided lattice not only reveals and complements the lace pattern, but also increases its decorative effect. The composition is framed with a frill of viliuski with filigree, decorated with vivaty loops.

Thus, the study of the compositional solution of the front and back sides of the fan contributed to the disclosure of the author's artistic intent. The drawing of the fan clearly reflects the attributes of the royal power. We admire the magical art of the lace-makers of the past, full of creative imagination, who created a complete composition that includes the balance of background and pattern, generality of forms, smoothness of the curving fork and the convention of transmitting pictorial floral motifs and Imperial symbols of power.

\section{Renovation of the fan of the Empress Maria Feodorovna}

In the traditional applied art of lace weaving, renovation (Lat. renovatio - 'renewal') includes: "the development of cultural heritage, the study of the historical period, the comprehension of technical traditions, the analysis of compositional solutions, the study of technology and material, the assimilation of the experience of previous artists, the use of the collective nature of work, the complete preservation of the spirituality of the folk-art tradition" (Lonchinskaya, 2011). It should note that the distinctive feature of renovation from restoration is the absence of interference with the material structure, violation of the aesthetic and historical 
values of the ancient work of art of lace weaving. During renovation, an old sample of lace is an object of study and knowledge and serves as a reference for recreating lost, forgotten technological techniques of weaving.

During the renovation of the fan of the Empress Maria Feodorovna, students had the opportunity:

- immerse themselves in the era;

- perform attribution (general description) of the work of lace art;

- analyse the technological features and artistic traditions of the corresponding historical period;

- understand the integration of these features and their relationship;

- analyse works of art contemporary to his era;

- study technology, technique elements of the art of lace-making;

- possess the ability to correct image transfer lace on paper and recreating exact replicas of Museum standard.

Modern lace-makers reproduced forgotten, lost technological techniques - relief 'cones', lattice medallions of multi-pair weaving techniques.

Thus, the development of renovation material by students including the study of compositional solutions, comprehension of technological, and technical techniques with full preservation of artistic traditions leads to a positive result - the creation of a historically reliable work of lace weaving art.

\section{Conclusion}

Thus, the lace fan of Empress Maria Feodorovna is of interest as a work of decorative and applied art of the $19^{\text {th }}$ century, which was executed in the Russian style. Wonderful lace, woven by the first students of the Mariinsky Practical School of Lace-Makers, is an excellent example of the art of lace-making preserving the traditions of Ancient Rus. The lace pattern has an allegorical meaning reflecting the status of the owner of the fan - the Empress Maria Feodorovna. Learning the secrets of the craft in the process of renovation leads to the discovery of unique techniques, understanding the beauty of the handmade work of lace-makers of the past centuries. Having mastered the skills of research work on renovation, students go to another level of creative activity, vision of the world, show creative activity in solving and implementing their creative ideas.

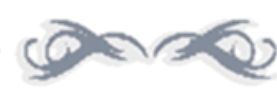

\section{References:}

Bernstein, B. M. (1979). Several considerations in connection with the problem of "art and ethnos". Soviet Art Studies '78: Collection of Articles, 2, 275-294. Moscow: Soviet Artist.

Davydova, S. A. (1892). Russian lace and Russian lace-makers: Historical, technical and statistical research.

St. Petersburg: Printing House of S.A. Suvorin.

Faleeva, V. A. (1983). Russian braided lace. Leningrad: Artist of the RSFSR.

Grebelsky, P. H., \& Mirvis, A. B. (1992). House of the Romanovs. St Petersburg: Ivan Fedorov's Publishing House. 
Lonchinskaya, T. E. (2011). Content of professional training in the renovation of art works of lace-making. Dissertation. St Petersburg Higher School of Folk Arts (Institute).

Plotnikov, Y. V., \& Yakovlev, L. A. (1997). Imperial fans from the Hermitage. Exbibition catalogue: The Fan Museum. London, 1997-98. St Petersburg: Slavia.

Sorokina, M. A. (2001). S.A. Davydova and the Mariinsky Practical School of Lace-Makers. Connection of Times: Materials of All-Russian Conference, 112-119. St Petersburg.

Spassky, I. G. (1963). Foreign and Russian orders before 1917. Leningrad: The State Hermitage.

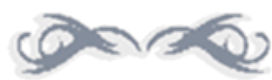

\section{Appendix}

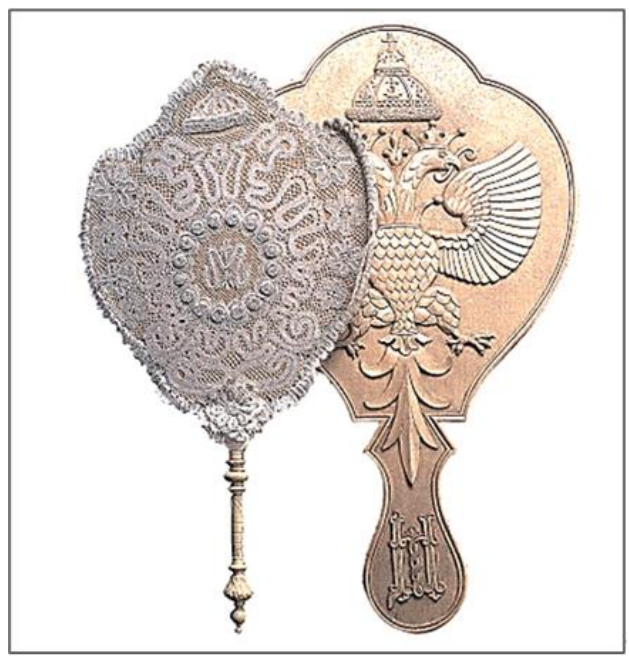

Figure 1. Lace fan. Russia. 1883

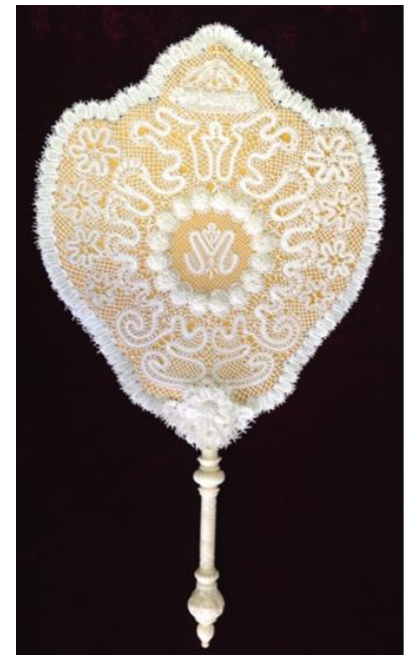

Figure 2. Front side of the fan (renovation). 2005

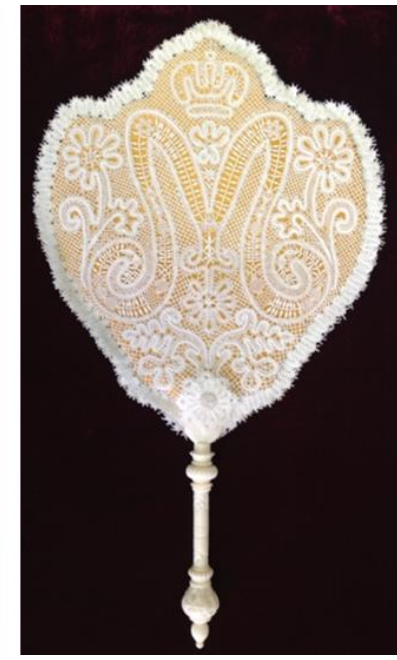

Figure 3. Reverse side of the fan (renovation). 2005

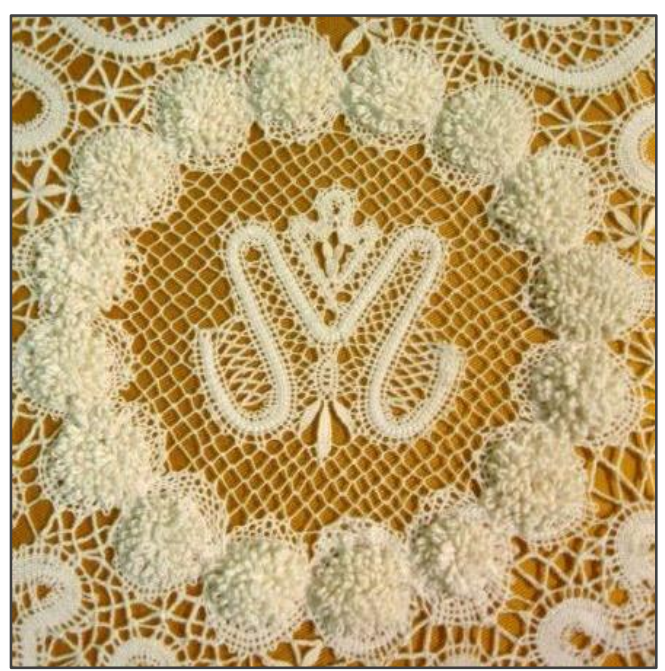

Figure 4. Terry 'cones' (renovation). 2005 